\title{
AKTIVITAS Bacillus subtilis PADA MEDIA TULANG AYAM DALAM PEMBENTUKAN GELATIN
}

\author{
Sudrajat Harris Abdulloh ${ }^{1}$, Bintang Iwhan Moehady ${ }^{1}$, Irwan Hidayatulloh, ${ }^{1, *}$ \\ ${ }^{1}$ Jurusan Teknik Kimia, Politeknik Negeri Bandung, Indonesia \\ *E-mail: irwan.hidayatulloh@polban.ac.id
}

\begin{abstract}
ABSTRAK
Gelatin merupakan bahan tambahan yang banyak terdapat pada industri makanan, minuman, dan tekstil. Gelatin terbentuk secara kimia melalui proses asam dan basa atau dengan bantuan aktivitas mikroorganisme. Proses kimia pembentukan gelatin membutuhkan waktu antara satu sampai lima minggu, sedangkan proses dengan aktivitas mikroorganisme terbentuk antara 12 sampai 24 jam. Penelitian ini bertujuan untuk membuat gelatin dengan menggunakan bakteri Bacillus subtilis ATCC No. 21228 serta bahan baku tulang ayam. Aktivitas bakteri Bacillus subtilis akan merombak kolagen dalam tulang ayam menjadi gelatin. Kondisi operasi yang digunakan yaitu: temperatur 45, 50, dan $55^{\circ} \mathrm{C}$; $\mathrm{pH} 7,8$, dan 9; dan konsentrasi $120 \mathrm{~g} / \mathrm{L}, 160 \mathrm{~g} / \mathrm{L}, 200 \mathrm{~g} / \mathrm{L}$ dan 240 $\mathrm{g} / 1$. Analisis terhadap produk yang diperoleh menggunakan uji kandungan protein dan uji pembentukan gelatin. Hasil penelitian menunjukkan kondisi optimum terjadi pada $\mathrm{pH}=9, \mathrm{~T}=$ $45^{\circ} \mathrm{C}$, konsentrasi $(\mathrm{C})=200 \mathrm{~g} / \mathrm{L}$, dan konversi rata-rata $=72,25 \%$.
\end{abstract}

Kata kunci: Gelatin, Bacillus subtilis, limbah tulang ayam

\begin{abstract}
Gelatin is an additive that is widely available in the food, beverage, and textile industries. It is formed chemically through acid and alkaline processes or with the help of microorganism activity. The chemical process for gelatin takes $1-5$ weeks, while the process with microorganism activity occur only 12-24 hours. This study aims to make gelatin using the bacteria Bacillus subtilis ATCC No.21228 from raw material for chicken bones. The activity of the Bacillus subtilis bacteria will convert collagen in chicken bones into gelatin. The operating conditions used in this work were: temperature under 45,50 , and $55^{\circ} \mathrm{C}$; $\mathrm{pH}$ between 7,8 , and 9; and concentrations of $120 \mathrm{~g} / \mathrm{L}, 160$ $\mathrm{g} / \mathrm{L}, 200 \mathrm{~g} / \mathrm{L}$ and $240 \mathrm{gr} / 1$. The result tested to obtain the existing protein and gelatin content. The results showed that the optimum conditions occurred at $\mathrm{pH}=9, \mathrm{~T}=45^{\circ} \mathrm{C}$, concentration $=200 \mathrm{~g} / \mathrm{L}$, and the average conversion $=72.25 \%$.
\end{abstract}

Keywords: Gelatin, Bacillus subtilis, chicken bone waste

\section{PENDAHULUAN}

Perkembangan ilmu pengetahuan tentang kesehatan akan meningkatkan kesadaran manusia pentingnya kebutuhan gizi yang menunjang aktivitas hariannya. Daging merupakan salah satu sumber kebutuhan gizi yang banyak dikonsumsi oleh manusia, diantaranya adalah daging sapi, kambing, ayam dan lainnya. Konsumsi daging hewan ini selalu menghasilkan sisa-sisa yang terbuang sebagai limbah berupa kulit, dan tulang.
Kulit hewan banyak menghasilkan produk-produk asesori, kerajinan atau industri kreatif lainnya, sedangkan tulang kebanyakan terbuang sebagai limbah atau menjadi bahan baku produksi bahan lainnya (Rahmawati dkk., 2019). Pada tulang masih banyak mengandung protein yang berupa kolagen. Kolagen inilah yang bisa dikonversi oleh aktivitas mikroorganisme menjadi gelatin (da Silva dkk., 2011; Hidayat dkk., 2016; Nagai \& Suzuki, 2000). 
Gelatin merupakan bahan tambahan dalam industri-industri makanan dan minuman, kertas dan tekstil, farmasi, dan fotografi. Industri makanan dan minuman menggunakan gelatin sebagai stabilizer dalam es krim, koloid pelindung dan agen pengemulsi dalam pembuatan marshmallows, krim dan permen, serta sebagai makan tambahan. Industri kertas dan tekstil menggunakan gelatin sebagai agent sizing. Industri fotografi menggunakan gelatin sebagai emulsi yang sensitif terhadap cahaya, sedangkan industri farmasi menggunakan gelatin sebagai bahan pembuatan kapsul (Liu dkk., 2008; Puspawati dkk., 2012).

Pengolahan gelatin secara kimia pada kulit hewan memerlukan waktu yang lama yaitu berkisar 1-5 minggu yang melibatkan proses perendaman kulit pada larutan asam atau basa yang menyebabkan kadar kolagen dalam kulit turun. (Fatimah \& Jannah, 2012) Pengolahan secara fermentasi memerlukan waktu 12-24 jam untuk menghidrolisis kolagen agar konversinya lebih tinggi. Enzim tersebut dapat dihasilkan sel mikroba yang pada umumnya berupa enzim ekstraselular. Penggunaan mikroba langsung dalam proses produksi ini yang perlu dikembangkan dalam penelitian ini agar perilaku proses dapat diketahui dan dipelajari.

Tujuan dari penelitian ini adalah untuk menentukan parameter-parameter kondisi optimum pada proses pengolahan tulang menjadi gelatin secara fermentasi. Parameter-parameter kondisi operasi yang menjadi lingkup penelitian ini adalah $\mathrm{pH}$, temperatur, konsentrasi padatan. Kemudian mikroba yang digunakan adalah Bacillus subtillis ATCC 21228. Gelatin dari hasil penelitian ini diharapkan dapat diterapkan kondisi operasi untuk digunakan dalam kajian produksi berskala besar.

\section{BAHAN DAN METODA}

Bahan baku penelitian ini adalah limbah tulang ayam dan mikroba Bacillus subtilis ATCC 21228. Metoda yang digunakan adalah fermentasi secara batch dengan variasi $\mathrm{pH}$, temperatur dan konsentrasi media.

\section{Pre-treatment}

Limbah tulang ayam melalui pengolahan awal dalam beberapa tahap, yaitu: pencucian, pengeringan pada oven $\left(50-60^{\circ} \mathrm{C}\right)$, penghancuran (grinding), dan pengayakan (sizing), dengan diameter $0,3555 \mathrm{~mm}$. Proses produksi gelatin melalui tahap fermentasi starter yang kemudian dipindahkan ke fermentor utama. Penggunaan media starter ini bertujuan untuk adaptasi awal dari mikroba Bacillus subtilis terhadap lingkungan yang mengandung tulang dan mempercepat waktu adaptasi ketika berada pada fermentor utama.

\section{Pembentukan Gelatin (Fermentasi)}

Limbah tulang ayam yang sudah melalui proses pre-treatment kemudian disterilisasi dengan pemanasan pada suhu $121^{\circ} \mathrm{C}$ selama 15 menit, bersamaan dengan inokulasi $20 \mathrm{ml}$ media starter biakan murni Bacillus subtilis selama 12 jam. Selanjutnya, pada fermentor utama dilakukan proses fermentasi selama 24 dengan beberapa variasi kondisi operasi yaitu kondisi $\mathrm{pH}$, suhu dan konsentrasi bahan baku terhadap media.

\section{Analisis Metode Kjeldahl}

Analisa dilakukan terhadap produk yang mencakup analisa protein untuk mengetahui kadar protein yang ada dalam tulang ayam dan kadar protein gelatin dengan metode Kjeldahl, Metode ini dilakukan melalui tahap destruksi, distilasi, dan titrasi. Metode destruksi bertujuan untuk menghancurkan sampel, sehingga larut dalam campuran dengan menambahkan $\mathrm{H}_{2} \mathrm{SO}_{4}$ dan garam 
Kjeldahl. Garam Kjeldahl berfungsi sebagai katalis. $\mathrm{H}_{2} \mathrm{SO}_{4}$ berfungsi untuk memecahkan $\mathrm{NH}_{3}$ yang terdapat dalam larutan. Distilasi bertujuan untuk menarik kembali $\mathrm{NH}_{3}$ dengan menambahkan $\mathrm{NaOH}$ sebagai penetral $\mathrm{H}_{2} \mathrm{SO}_{4}$. Pada proses distilasi uap $\mathrm{NH}_{3}$ akan ditampung pada larutan asam borat. Larutan asam borat ini berfungsi untuk menangkap kembali uap $\mathrm{NH}_{3}$ yang sudah terkondensasi. Setelah distilat terbentuk dilakukan titrasi dengan larutan asam $(\mathrm{HCl})$ yang bertujuan untuk mengetahui

Proses pembuatan gelatin dilakukan secara fermentasi batch yang merupakan hasil perombakan protein dari tulang ayam oleh mikroorganisme Bacillus subtilis. Penelitian ini menggunakan media tulang ayam sebagai sumber protein yang bermanfaat bagi mikroba dalam pertumbuhannya. Sasaran penelitian ini untuk mengetahui kondisi

\section{Kurva Panjang Gelombang Maksimum}

Penentuan panjang gelombang ini dilakukan terhadap satu sampel larutan baku untuk kurva pertumbuhan dengan variasi panjang gelombang untuk mendapatkan persen absorbansinya. Variasi panjang gelombang tersebut menghasilkan panjang gelombang maksimum yang menunjukkan serapan cahaya maksimum sepeerti Gambar 1 . Pada percobaan ini didapatkan panjang gelombang maksimum sebesar $540 \mathrm{~nm}$ pada absorbansi 17\%. Nilai panjang gelombang ini digunakan sebagai panjang gelombang pada pembuatan kurva pertumbuhan. kadar nitrogen yang terdapat dalam larutan.

\section{Analisa kehadiran gelatin}

Gelatin hasil fermentasi diketahui eksistensinya dengan metode pengendapan menggunakan bahan kimia (detection of thickening), adanya produk gelatin ditandai dengan terjadinya pengendapan gelatin yang berwama kuning susu setelah ditambahkan larutan asam nitrat dan asam pikrat.

\section{HASIL DAN PEMBAHASAN}

optimum pertumbuhan mikroba dalam menghasilkan produk gelatin yang optimum berdasarkan pada kondisi temperatur, $\mathrm{pH}$, dan konsentrasi media. Parameter pengukuran keberhasilan proses fermentasi dilihat dari kinetika fermentasi yang meliputi penggunaan substrat yang dianalisis pada keadaan awal dan akhir.

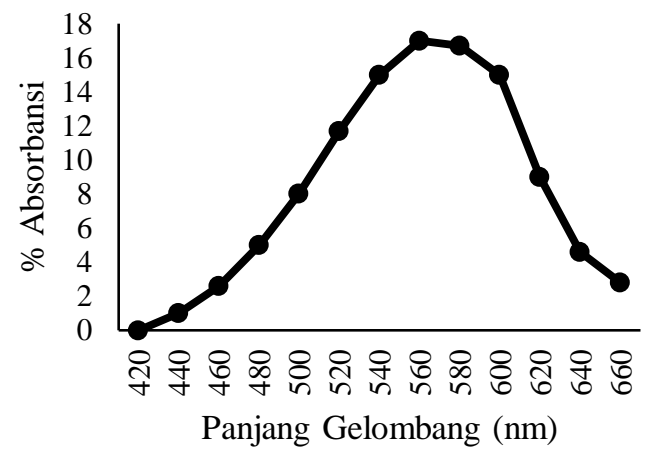

Gambar 1. Kurva Panjang Gelombang Maksimum

Bakteri pada umumnya mengalami pertumbuhan secara bertahap dalam waktu tertentu sesuai dengan sifat masing-masing mikroorganisme tersebut, ada yang membutuhkan waktu yang lama dan ada juga membutuhkan waktu yang singkat. Hal ini dapat terlihat pada kurva pertumbuhan bakteri Bacillus subtillis, yang pertumbuhannya sampai mencapai keadaan fase stationer membutuhkan waktu 18 jam dan dalam waktu tersebut biomassa tersebut telah mengalami beberapa fasa pertumbuhan. 
Kurva pertumbuhan bakteri Bacillus subtilis tersebut dapat dilihat pada Gambar 2.

Pada fasa awal (lag phase) diperkirakan dari kurva pertumbuhannya, biomassa ini cenderung tidak mengalami peningkatan jumlah set. Hal ini disebabkan mikiroorganisme ini cenderung berusaha untuk menyesuaikan diri dengan lingkungan yang baru, pada saat terjadi sintesa enzim oleh sel untuk kebutuhan metabolisme metabolitnya. Pada saat itu juga terjadi germinasi spora (spora tumbuh) dan metabolisme dari spora belum aktif sehingga selnya disebut set vegetatif. Fasa ini biasanya tidak berlangsung terlalu lama yang pada biomassa Bacillus subtilis ini berlangsung antara jam ke-0 sampai dengan jam ke-3, yang kemudian setelah fasa ini selesai maka dimulailah fasa pertumbuhan yang dipercepat pada jam ke-3 sampai dengan jam ke-5, pada fasa ini terjadi peningkatan konsentrasi biomassa perlahan-lahan dan semakin meningkat dengan laju pertumbuhan mengikuti persamaan $\mathrm{dx} / \mathrm{dt}$.

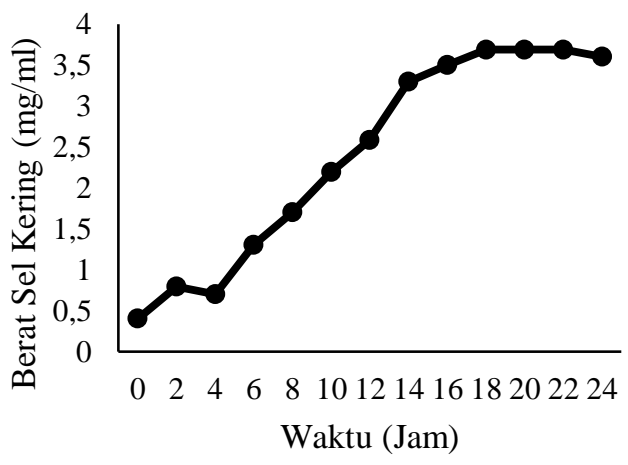

Gambar 2. Kurva Pertumbuhan Bacillus subtilis

Keadaan menyebabkan sel cenderung untuk memperbanyak diri dan ukuran selnya mencapai maksimum, sedang waktu populasi sel dalam melipatkan diri dalam jumlahnya menjadi dua kali lipat. Fasa ini hanya berlangsung beberapa saat saja untuk mencapai maksimalnya, dan setelah itu langsung mengalami fasa logaritmik (eksponensial) dimana pada fasa ini terjadi pertumbuhan mikroba dengan cepat dan konstan mengikuti peningkatan waktu. Dari kurva pertumbuhan di atas ini terlihat bahwa pada fase eksponensial (jam ke-5 sampai dengan jam ke-14) laju pertumbuhan spesifiknya tetap dan mencapai nilai maksimal. Pada keadaan ini pertumbuhan dinyatakan :

$$
\begin{gathered}
\frac{d C x}{d t}=\mu . C x \\
f \frac{d C x}{C x}=f \mu . d t \\
\ln C x=\mu . t \\
\ln C x-\ln C x_{0}=\mu
\end{gathered}
$$

Mikroorganisme tumbuh dalam spektrum lingkungan fisik dan kimiawi yang sangat luas. Mikroorganisme bertumbuh artinya massa sel dan jumlah sel meningkat, ini terjadi hanya jika kondisi kimiawi dan fisik terpenuhi, diantaranya: suhu, $\mathrm{pH}$, dan konsentrasi substrat yang sesuai dan tersedianya nutrien.

Laju pertumbuhan biomassa ini tidak hanya terus berada pada tahap/fase eksponensial tapi akan berubah. Sepanjang fermentasi, komposisi kimiawi cairan fermentasi berubah berhubung nutrien terus menerus dikomsumsi oleh mikroorganisme dan pembentukan produk. Nutrien yang terus-menerus dikonsumsi dan bertambahnya biomassa akan menyebabkan berkurangnya nutrien dan terjadi persaingan antara biomassa dalam mengkonsumsi nutrien. Pada keadaan ini penumpukan produk akan terus meningkat sedangkan kebutuhan nutrien akan semakin banyak namun nutrien tidak cukup tersedia maka akan tercapai laju pertumbuhan nol, yaitu : fasa stationer (jam ke-18 sampai dengan jam ke-22), dimana jumlah mikroba 
yang mati lama dengan jumlah mikroba yang hidup.

Masa sel total dapat tetap konstan, tetapi jumlah sel cenderung menurun. Pada saat ketahanan hidup menurun yaitu karena karena jumlah nutrien yang berkurang dan terjadi akumulasi produk yang menjadi racun dan merupakan penghambat pertumbuhan, maka terjadi penurunan laju pertumbuhan. Pada fase stationer ini, konsentrasi biomasa maksimal dan pertumbuhan berhenti dan menyebabkan terjadinya modifikasi struktur biokimiawi sel. Fase stationer ini ditandai dengan berkurangnya jumlah sel hidup dalam media akibat terjadinya kematian yang diikuti oleh autolisis oleh enzim sellular. Kurva pertumbuhan akan memasuki fase kematian (jam ke-22 - ) dimana jumlah set yang mati lebih banyak daripada yang hidup.

\section{Nutrisi}

Nutrisi merupakan unsur-unsur yang diperlukan oleh mikroorganisme untuk proses metabolisme. Secara spesifik unsur $\mathrm{N}$ berfungsi untuk pembentukan sel-sel baru mikroorganisme dan dalam pembentukan asam nukleat dan koenzim. Koenzim ini merupakan bagian vital dalam membuat suatu enzim menjadi lebih aktif dan enzim sendiri merupakan faktor penting dalam pendegradasian substrat. Peningkatkan aktivitas mikroorganisme dan perbaikan kualitas unsur hara mikroorganisme perlu ditambahkan pada media starter, berupa $\left(\mathrm{NH}_{4}\right)_{2} \mathrm{SO}_{4}$, yang bersifat tambahan namun merupakan faktor yang mempengaruhi aktivitas dari mikroorganisme. Unsur $\mathrm{N}$ yang menjadi sumber nutrisi mikroorganisme pada tulang ayam berbentuk molekul besar berupa protein, Gambar 3 menunjukkan persentase protein berdasarkan konsentrasi tulang ayam yang digunakan.

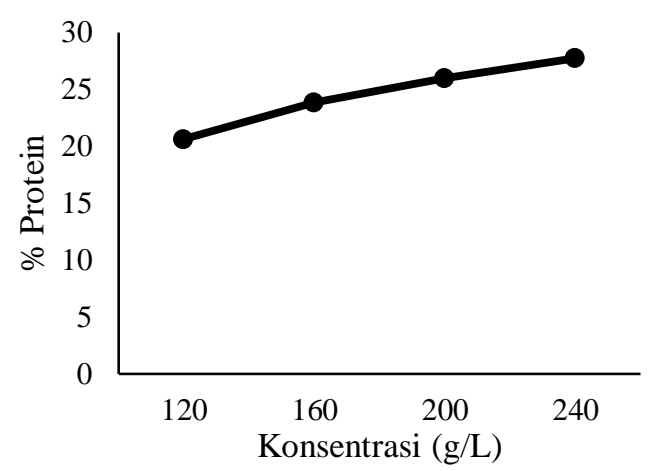

Gambar 3. Grafik Kandungan Protein dari Tulang Ayam (Protein Awal)

\section{Pengaruh Perbedaan Temperatur}

Variasi temperatur yang digunakan pada penelitian ini berkisar antara $45-55^{\circ} \mathrm{C}$. Temperatur tersebut adalah temperatur pertumbuhan optimum bakteri Bacillus Subtilis, pada temperatur ini proses pertumbuhan Bacillus Subtilis adalah optimum dan pertumbuhannya tidak terhambat. Fermentasi bakteri Bacillus subtilis ini dilakukan dengan tiga variasi temperatur, yaitu pada suhu $45^{\circ} \mathrm{C}, 50^{\circ} \mathrm{C}$, dan $55^{\circ} \mathrm{C}$, yang mula-mula dilakukan fermentasi pada media starter dengan waktu 12 jam, kemudian dari media starter tersebut dipindahkan ke media fermentor utama untuk diinkubasikan selama 24 jam, dimana selama waktu inkubasi dilakukan pengadukan dengan menggunakan shaker.

Temperatur ini merupakan salah satu faktor penentu keberhasilan proses fermentasi gelatin, karena temperatur ini memberikan indikasi cepat tidaknya proses fermentasi dan banyak produk gelatin yang terbentuk. Adapun produk gelatin yang terbentuk terhadap pengaruh temperatur ini dapat dilihat pada Grafik 4. Sebagai berikut. 


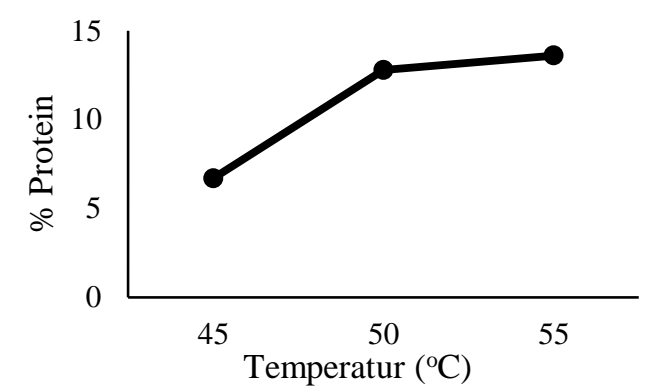

Gambar 4. Grafik Kandungan Protein Pengaruh Temperatur (Protein sisa)

Dari Gambar 4 di atas terlihat bahwa kadar protein yang tersisa dalam larutan gelatin lebih sedikit pada kondisi suhu $45^{\circ} \mathrm{C}$. Hal ini menunjukkan bahwa pembentukan gelatin secara fermentasi optimum pada suhu tersebut karena protein lebih banyak diubah menjadi gelatin.

Temperatur ini sangat mempengaruhi jumlah produk gelatin yang dihasilkan. Temperatur berbanding lurus nilainya dengan panas/energi yang berasal dari reaksi fermentasi oleh mikroorganisme. Jika panas yang dihasilkan dari reaksi cukup besar dan panas tersebut bertahan dalam media, maka temperature media akan naik dan jika panas yang dihasilkan dari hasil reaksi fermentasi kecil, maka temperature media akan kecil. Temperatur media ini menunjukkan tingkat aktivitas mikroorganisme dalam mendegradasi bahan organik.

\section{Pengaruh Perbedaan pH Awal}

Variasi kedua dilakukan terhadap variasi $\mathrm{pH}$, yang dilakukan dengan tiga jenis variasi, yaitu $\mathrm{pH} 7,8$ dan 9 . Adapun pemilihan $\mathrm{pH}$ ini adalah berdasarkan range $\mathrm{pH}$ pertumbuhan optimum dari bakteri Bacillus Subtilis, yaitu pada $\mathrm{pH} 7-8$. Pengendalian $\mathrm{pH}$ disini dilakukan hanya pada saat awal sebelum fermentasi dimulai pada konsentrasi masing-masing media, baik media starter maupun media fermentasi. Dengan demikian setelah media starter mengalami proses fermentasi $\mathrm{pH}$-nya tidak dikendalikan lagi, tapi langsung dipindahkan pada media fermentasi yang memiliki $\mathrm{pH}$ yang telah diset sesuai kebutuhan.

Pengendalian $\mathrm{pH}$ disini dilakukan dengan penambahan $\mathrm{NaOH} / \mathrm{HCl}$ pada media sebelum disterilisasi. Sedangkan temperatur yang digunakan pada saat fermentasi dengan variasi $\mathrm{pH}$ ini adalah temperatur optimum yang diperoleh berdasarkan variasi temperatur diatas, yaitu pada suhu $45^{\circ} \mathrm{C}$. $\mathrm{pH}$ media fermentasi dalam reaktor fermentasi sangat berpengaruh dalam pertumbuhan mikroorganisme dan cara kerja enzim mengkonversi protein. Perubahan $\mathrm{pH}$ dalam media akan menyebabkan perubahan pada sistem kerja enzim dan substrat.

Adapun produk gelatin yang terbentuk terhadap pengaruh variasi $\mathrm{pH}$ ini dapat dilihat pada Gambar 5. di bawah ini.

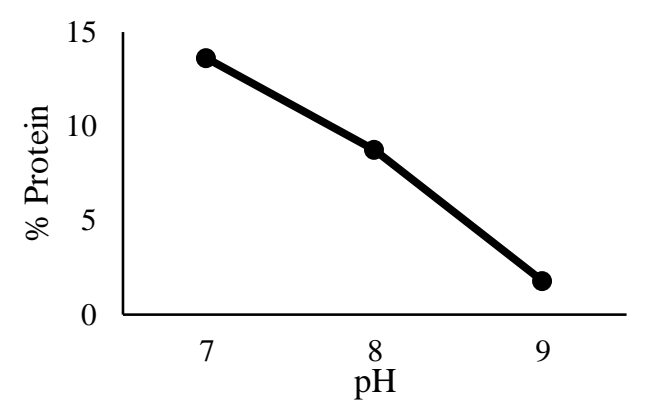

Gambar 5. Grafik Kandungan Protein terhadap Pengaruh pH (Protein sisa)

Dilihat dari kurva tersebut, dimana pada $\mathrm{pH}$ yang berbeda, pembentukan produk gelatin juga berbeda. Kemudian terlihat bahwa kandungan protein sisa pada produk gelatin lebih kecil pada $\mathrm{pH}$ 9. Hal ini menandakan bahwa protein yang diubah membentuk gelatin secara fermentasi lebih banyak pada $\mathrm{pH}$ tersebut dan kondisi ini merupakan kondisi optimum untuk $\mathrm{pH}$. Terjadinya penurunan $\mathrm{pH}$ pada proses fermentasi tersebut dikarenakan terbentuknya asam organik dari karbohidrat. 


\section{Pengaruh Perbedaan Konsentrasi}

Variasi ketiga dilakukan terhadap variasi konsentrasi, yang dilakukan berdasarkan volume media yang digunakan dan disesuaikan dengan komposisi bahan baku. Pada variasi ini dilakukan dengan 4 jenis variasi konsentrasi, dengan batasan konsentrasi berdasarkan literatur yang diperoleh. Adapun variasi konsentrasi yang dilakukan yaitu $120 \mathrm{~g} / \mathrm{L}, 160 \mathrm{~g} / \mathrm{L}, 200$ $\mathrm{g} / 1$, dan $240 \mathrm{~g} / \mathrm{L}$, dengan volume media fermentasi $100 \mathrm{ml}$. Konsentrasi media starter diberikan lebih kecil dari konsentrasi media fermentor utama, karena media starter ini berfungsi sebagai tempat adaptasi awal terhadap biomassa, sedangkan temperatur dan $\mathrm{pH}$ yang digunakan adalah berdasarkan temperatur dan $\mathrm{pH}$ optimum yang diperoleh berdasarkan variasi terdahulu.

Adapun produk gelatin yang terbentuk terhadap pengaruh variasi konsentrasi ini dapat dilihat pada gambar di bawah ini :

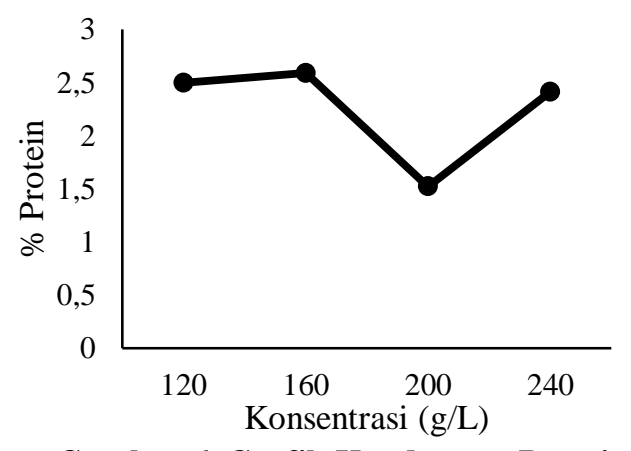

Gambar 6. Grafik Kandungan Protein terhadap Pengaruh Konsentrasi (Protein sisa)

Berdasarkan gambar grafik diatas terlihat bahwa kandungan protein pada konsentrasi $200 \mathrm{~g} / \mathrm{L}$ diperoleh lebih kecil. Hal ini menandakan bahwa kandungan gelatin lebih banyak diperoleh pada konsentrasi tersebut, karena protein yang diubah lebih banyak dibandingkan dengan konsentrasi lainnya. Konsentrasi substrat ini sangat berpengaruh pada proses degradasi mikroorganisme membentuk produk gelatin. Jika dilihat pada konsentrasi yang lebih tinggi yaitu pada konsentrasi $240 \mathrm{~g} / \mathrm{L}$ terjadi penurunan kenaikan kandungan protein, hal ini disebabkan oleh jumlah substrat yang terkandung dalam media berlebih dibanding dengan mikroba yang digunakan. Penyebabnya karena dengan kelebihan substrat yang terdapat dalam larutan media fermentasi dapat menghambat proses pertumbuhan dari mikroorganisme yang terlibat, sehingga kelebihan substrat tersebut dapat menyebabkan bahan yang beracun (toxic) bagi mikroorganisme tersebut.

\section{Konversi Pembentukan Gelatin}

Konversi dari gelatin yang dihasilkan terhadap total kandungan protein yang terdapat dalam tulang ayam lebih banyak pada kondisi temperatur 45 ${ }^{\circ} \mathrm{C}$, pH 9 dan konsentrasi $200 \mathrm{~g} / \mathrm{L}$. Hal ini dapat dilihat pada grafik berikut ini :

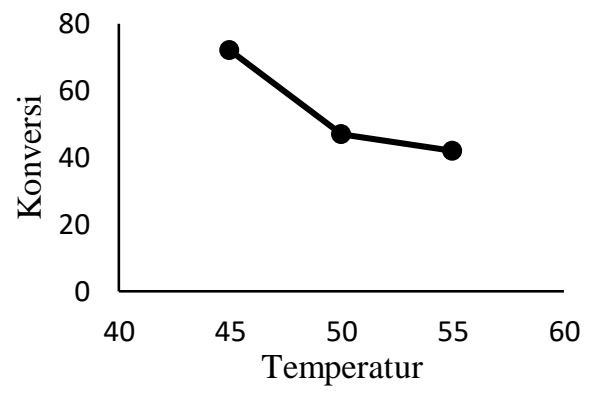

Gambar 7. Konversi Protein Terhadap Pengaruh Temperatur

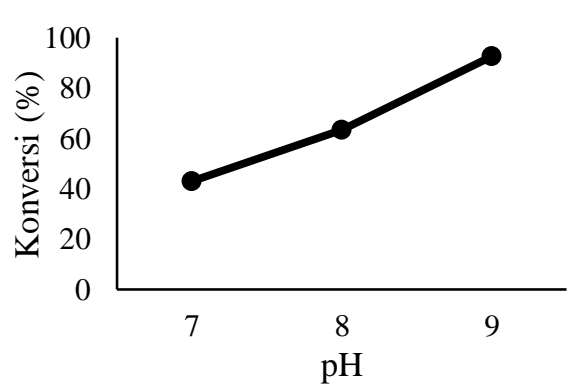

Gambar 8. Konversi Protein Terhadap Pengaruh pH 


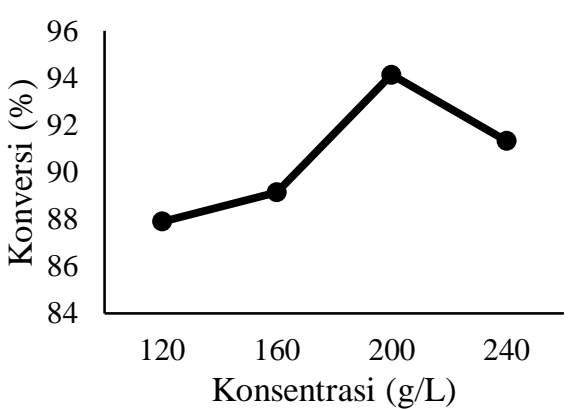

Gambar 9. Konversi Protein terhadap Pengaruh Konsentrasi

Berdasarkan hasil penelitian didapatkan kondisi optimum untuk mendapatkan konversi protein menjadi gelatin paling besar adalah pada kondisi.

- Temperatur : $45^{\circ} \mathrm{C}$

- $\mathrm{pH}: 9$

- Konsentrasi : 200g/L

\section{KESIMPULAN}

Melalui penelitian ini dapat disimpulkan bahwa uji kehadiran gelatin menunjukkan adanya kandungan gelatin yang ditandai dengan terbentuknya endapan kuning susu. Waktu maksimum yang dibutuhkan untuk mencapai pertumbuhan Bacillus subtilis untuk menghasilkan gelatin adalah 18 jam dan kondisi operasi optimum yang diperoleh pada penelitian ini adalah: temperatur $45^{\circ} \mathrm{C}, \mathrm{pH}=9$ dan konsentrasi media $=200$ $\mathrm{g} / \mathrm{L}$

\section{UCAPAN TERIMAKASIH}

Kami ucapkan terima kasih kepada Sdr. Rabin Handeni Saragih dan Sdr. Wahyu Setiawan yang telah berpartisipasi dalam penelitian ini.

\section{Daftar Pustaka}

da Silva, R. S. G., Bandeira, S. ., Petry, F. ., \& Pinto, L. a. . (2011). Effect of bone particle size of carp (Cyprinus Carpio) heads in gelatin extraction. VETOR-Revista de Ciências Exatas e Engenharias, 21(2), 34-43.

Fatimah, D., \& Jannah, A. (2012). Efektivitas Penggunaan Asam
Sitrat Dalam Pembuatan Gelatin Tulang Ikan Bandeng (ChanosChanos Forskal). Alchemy.

Hidayat, G., Nurcahya Dewi, E., \& Rianingsih, L. (2016). Characteristics of Bone Gelatin Tilapia (Oreochromis niloticus) Processed by Using Hydrolysis With Phosphoric Acid and Papain Enzyme. Jurnal Pengolahan Hasil Perikanan Indonesia, 19(1), 69-78.

Liu, H., Li, D., \& Guo, S. (2008).

Rheological properties of channel catfish (Ictalurus punctaus) gelatine from fish skins preserved by different methods. LWT - Food Science and Technology, 41(8), 1425-1430.

Nagai, T., \& Suzuki, N. (2000). Isolation of collagen from fish waste material - Skin, bone and fins. Food Chemistry, 68(3), 277-281.

Puspawati, N., Simpen, I., \& Sumerta Miwada, I. (2012). Isolasi Gelatin Dari Kulit Kaki Ayam Broiler Dan Karakterisasi Gugus Fungsinya Dengan Spektrofotometri Ftir. Jurnal Kimia, 6(1).

Rahmawati, D., Setyadewi, N. M., \& Sugihartono. (2019). Extraction and characterization of gelatin from skin trimming pickled waste of tannery. IOP Conference Series: Earth and Environmental Science, 306(1). 